\title{
Transtornos de linguagem oral em crianças pré-escolares com epilepsia: screening fonoaudiológico****
}

\author{
Oral language disorders in preschool children with epilepsy: a \\ speech-language screening
}

\author{
Patrícia Danielle Falcão Melo* \\ Áurea Nogueira de Melo** \\ Eulália Maria Chaves Maia***
}

\begin{abstract}
*Fonoaudióloga. Doutoranda do Programa de Pós-Graduação em Ciências da Saúde da Universidade Federal do Rio Grande do Norte (UFRN). Docente da Especialização em Linguagem da Universidade Potiguar (UnP). Endereço para correspondência: Av. Abel Cabral, 484 - Apto. 303 -

Bloco A - Parnamirim - RN. CEP 59151-250

(patriciamelo77@gmail.com).
\end{abstract}

**Médica. Pós-Doutorado pela Johns Hopkins University and Hospital (JHUH) - Estados Unidos. Professora Adjunta do Departamento de Pediatria - Setor de Neurologia Infantil da Universidade Federal do Rio Grande do Norte (UFRN)

***Psicóloga. Doutora em Psicologia Clínica pela Universidade de São Paulo. Professora Associada II do Departamento de Psicologia da UFRN.

****Trabalho Realizado no Hospital de Pediatria Professor Heriberto Bezerra - Setor de Neurologia Infantil da UFRN.

Artigo Original de Pesquisa

Artigo Submetido a Avaliação por Pares

Conflito de Interesse: não

Recebido em 15.01.2009.

Revisado em 15.05.2009; 20.01.2010. Aceito para Publicação em 01.02.2010.

\begin{abstract}
Background: oral language disorder and epilepsy in childhood. Aim: to verify the occurrence of oral language disorders in epileptic preschoolers attended at the Child Neurology Section of a university hospital. Method: a prospective study with 30 epileptic children who were submitted to an oral speechlanguage evaluation. Inclusion criteria: explicit diagnosis of epilepsy according to the ILAE (2005); ages between 3 to 6 years; normal neurological standard and neuropsychomotor development. Exclusion criteria: dubious diagnosis of epilepsy; altered neurological standard and neuropsychomotor development; children with associated pediatric disorders. Analyzed variables were: gender, age of first seizure, types of seizure and treatment regime. OR (odds ration) was determined, with a significance level of $<0.05$. Results: 18 (60\%) children with epilepsy presented oral language disorders and 12 (40\%) presented normal language development. Regarding the observed disorders, 12 (67\%) presented language disorder and $6(33 \%)$ presented phonological disorder. Male children $(\mathrm{OR}=2.03)$ and those with partial seizure $(\mathrm{OR}=2.41)$ demonstrated to have a higher risk for oral language disorders. Conclusion: the results indicate that preschoolers with epilepsy present a predominance of oral language development delay, and that the male gender and partial seizure are risk factors for this age group.
\end{abstract}

Key Words: Language Disorders; Epilepsy; Children; Preschoolers.

\section{Resumo}

Tema: transtornos de linguagem oral e epilepsia em pré-escolares. Objetivo: verificar a ocorrência de alterações de linguagem oral em pré-escolares com epilepsia atendidos no Setor de Neurologia Infantil de um hospital universitário. Método: estudo prospectivo realizado com 30 crianças com epilepsia, submetidas à avaliação fonoaudiológica de linguagem oral. Critérios de inclusão: diagnóstico inequívoco de epilepsia segundo a definição da ILAE (2005) ${ }^{12}$; idade de 3 aos 6 anos; padrão neurológico e desenvolvimento neuropsicomotor normais. Exclusão: diagnóstico de epilepsia duvidoso; padrão neurológico e desenvolvimento neuropsicomotor alterados; crianças com patologias pediátricas associadas. Variáveis analisadas: sexo, idade da primeira crise epiléptica, tipo de crise epiléptica e regime de tratamento. Determinou-se OR (razão de chances), adotando-se < 0,05. Resultados: 18 (60\%) crianças com epilepsia apresentaram alterações de linguagem oral e, 12 (40\%), linguagem oral dentro dos padrões de normalidade. Em relação às alterações, 12 (67\%) apresentaram transtorno de linguagem e 6 (33\%) apresentaram desvio fonológico. Crianças do sexo masculino $(\mathrm{OR}=2,03)$ e as com crise epiléptica do tipo parcial $(\mathrm{OR}=2,41)$ mostraram maior chance de apresentar alterações de linguagem oral. Conclusão: o estudo mostrou em pré-escolares com epilepsia: predomínio de atraso no desenvolvimento da linguagem oral, e o sexo masculino e a crise epiléptica do tipo parcial como fatores de risco para essa faixa etária.

Palavras-Chave: Transtornos da Linguagem; Epilepsia; Crianças; Pré-Escolares. 


\section{Introduction}

The etiology of alterations in oral language, phonological disorders and language disorders varies and may involve factors such as: organic, intellectual / cognitive, environmental and emotional which most of the time happens to have an interrelationship among all these factors1-2. From all of them, it is highlighted the role of epilepsy which recent studies3-6 have identified neuropsychological impairments and alterations related to the language development.

Children with epilepsy are particularly vulnerable to language disorders and, therefore, to educational problems and emotional maladjustments5. The age of early onset of epilepsy has been implied as an important factor for the occurrence of oral language alterations7; however, there are other relevant aspects, for instance: frequency of seizures, late medicine intervention, type of seizure and polytherapy 8-9.

Besides the physiologic alterations, these individuals also suffer with the illness psychosocial effects. The word "epilepsy" brings attached a kind of stigma that hinders individuals with it to have a social life. The change of behavior and the influence of epilepsy can be observed since early childhood when the first social adaptation difficulties come to light10.

It is strongly relevant to investigate the possibility of oral language disorder occurrences in children with epilepsy because there are not many researches in this field $4,11$.

The purpose of this work is to verify oral language alteration occurrences in pre school students with diagnosis of epilepsy who were attended at the child neurology section in a university hospital.

\section{Method}

It was performed a prospective study with a convenience sample of preschool age children with unequivocal diagnosis of epilepsy. These patients were submitted to a phonoaudiologic evaluation of oral language, over a period of five months, from November of 2007 to April of 2008.

The study was carried out in the epilepsy outpatient care section for children at the Pediatric Hospital (Hospital de Pediatria -HOSPED) at Universidade Federal do Rio Grande do Norte (UFRN) - Brazil.
The selection criteria were:

Inclusion criteria:

1. Unequivocal diagnosis of epilepsy, according to the definition of ILAE (2005)12;

2. Age from 3 to 6 ;

3. Normal neurological pattern and neuropsychomotor development;

4. Parents or responsible for the kids were requested to sign a free and informed consent form.

\section{Exclusion criteria:}

1. Doubtful diagnosis of epilepsy;

2. Altered neurological pattern and neuropsychomotor development;

3. Children with associated pediatric pathologies

\section{Procedures}

Patients were selected, and then parents and/ or responsible ones had access to all information concerning the research by the Free and Informed Consent Form.

The demographic and clinical variables analyzed - gender, age of first seizure, type of seizure and mode of treatment - were collected from the medical record evaluation form at the child neurology section of HOSPED, concomitantly to the patient care.

The oral language phonoaudiologic evaluation was performed during the outpatient care consultation routine, following the evaluation protocol adapted by the researchers (appendix). It was evaluated the interdependent systems: phonology13, morphosyntax14, semantic15 and pragmatic16:

1. Phonological level: the balanced drawings of Yavas et tal13 were used, under the aspects of naming and word repetition as well as spontaneous speech.

2. Morphosyntax level: it was used as an evaluation tool the text "The Crab" (O caranguejo) by Braz \& Pelliccioti14, which aimed to evaluate the production process under the morphosyntax aspect. In the child's speech, were observed the phrasing structures, use of connectives and temporal elements, plus the type of sentences and clauses chosen by the subjects; lengthiness of sentences and occurrences of mistakes during verbal and nominal inflections. 
3. Semantic level: it was used the semantic development assessment tool of Acosta15, which aims to evaluate the comprehension processes and production at the semantic level, under the aspects of denomination and categorization. It was shown to the children eight cards in two different categories (four from each one), thus, they were asked to find and to name the card that corresponded to the descriptions they were given.

4. Pragmatic level: it was evaluated during the whole interaction process, between the child and the therapist, being collected sample of spontaneous speech, as suggested by Acosta15, who states that this level evaluates the functioning of the speech, in social, situational and communicative contexts.

For purposes of analysis of the oral language assessment, the results were divided as follow:

1. Oral language within the normal patterns.

2. Occurrence of oral language alterations.

2.1. Language disorder;

2.2. Phonological disorder.

Statistical analysis

All of the calculation procedures were done using the software Statistica for Windows, version 6.2. Firstly, it was performed the descriptive analysis of the data, getting then, the absolute and relative frequency of all the variables in this study. Secondly, it was determined the variables Odds Ratio (OR), adopting a confidence interval of $95 \%$.
This research was approved by the Ethics Committee in Research of University Hospital Onofre Lopes, in 10/26/07, registered as protocol number 105/07. All of the patients' relatives had access to information concerning the study, by means of The Free and Informed Consent Form, thus, they could authorize or not the inclusion of the patient in the study as well as in dissemination of results in accordance with the resolution 196/96, which deals with the question of ethics when human beings are subject of researches.

\section{Results}

It was selected 30 preschool children with epilepsy. Out of the total amount of children, 18 (60\%) presented oral language alterations and 12 (40\%) presented oral language within the normal patterns. Regarding the alterations, 12 (67\%) presented language disorder and 6 (33\%) phonological disorder.

The distribution of presence or absence of oral language alterations related to variables such as: gender, age of first seizure, type of seizure and medicine treatment is shown in table 1.

The odds ratio (OR) of variables regarding the presence of "oral language disorders" or "oral language within normal patterns" showed association (table 2) in relation to the variables "gender" and "oral language alterations":

$\mathrm{OR}=$ 2, 03 and IC [2, 03 - 13, 32] and "type of seizure" and "oral language alterations": $\mathrm{OR}=2,41$ and IC [1, 13 - 8, 74]. 
TABELA 1. Distribution of presence or absence regarding oral language alterations in 30 preschool children with epilepsy in relation to the studied variables.

\begin{tabular}{|c|c|c|c|c|c|c|c|}
\hline & \multicolumn{4}{|c|}{ Oral language alterations } & \multicolumn{2}{|c|}{$\begin{array}{l}\text { Oral language within normal } \\
\text { patterns }\end{array}$} & \multirow[t]{2}{*}{ Total } \\
\hline & \multicolumn{2}{|c|}{ Phonological disorder } & \multicolumn{2}{|c|}{ Language disorder } & \multirow[b]{2}{*}{$\mathrm{N}$} & \multirow[b]{2}{*}{$\%$} & \\
\hline & $\mathrm{N}$ & $\%$ & $\mathrm{~N}$ & $\%$ & & & $\mathrm{~N}$ \\
\hline \multicolumn{8}{|l|}{ Gender } \\
\hline Male & 4 & 22 & 9 & 54 & 4 & 24 & 17 \\
\hline Female & 2 & 15 & 3 & 23 & 8 & 62 & 13 \\
\hline Total & 6 & 20 & 12 & 40 & 12 & 40 & 30 \\
\hline \multicolumn{8}{|c|}{ Age of first seizure } \\
\hline$<2$ years & 2 & 11 & 11 & 58 & 6 & 32 & 19 \\
\hline$>2$ years & 4 & 36 & 1 & 9 & 6 & 55 & 11 \\
\hline Total & 6 & 20 & 12 & 40 & 12 & 40 & 30 \\
\hline \multicolumn{8}{|l|}{ Type of seizure } \\
\hline Partial & 3 & 20 & 8 & 53 & 4 & 27 & 15 \\
\hline Generalized & 3 & 20 & 4 & 27 & 8 & 53 & 15 \\
\hline Total & 6 & 20 & 12 & 40 & 12 & 40 & 30 \\
\hline \multicolumn{8}{|c|}{ Type of medicine treatment } \\
\hline Monotherapy & 6 & 22 & 11 & 39 & 11 & 39 & 28 \\
\hline Polytherapy & 0 & 0 & 1 & 50 & 1 & 50 & 2 \\
\hline Total & 6 & 20 & 12 & 40 & 12 & 40 & 30 \\
\hline
\end{tabular}

TABELA 2. The odds ratio of selected variables regarding the presence or the absence of oral language alterations in 30 preschool children with epilepsy.

\begin{tabular}{lcc}
\hline \multicolumn{1}{l}{ Variables } & OR & IC $(95 \%)$ \\
\hline Sexo & & \\
Male x Female & $\mathbf{2 , 0 3}$ & {$[\mathbf{2 , 0 3}-\mathbf{1 3 , 3 2}]$} \\
Age of first seizure & & \\
$<2$ years x $>2$ years & 1,81 & {$[1,00-6,76]$} \\
Type of seizure & & \\
Partial x Generalized & $\mathbf{2 , 4 1}$ & {$[\mathbf{1 , 1 3}-\mathbf{8 , 7 4}]$} \\
Type of medicine treatment & & \\
Monotherapy x Polytherapy & 1,75 & {$[0,59-5,17]$} \\
\hline
\end{tabular}

\section{Discussion}

In this prospective study, although it is common parents do not complain about oral language alterations, it is necessary to call attention to significant occurrence of oral language disorders in preschool children with epilepsy.

The etiology of oral language disorder may be related to emotional problems, congenital diseases, mental retardation and/or neurological problems2, which have epilepsy as a highlighted element6.

The normal development of language happens due to the balance of the child individual characteristics, including his/her genetic basis and also environmental characteristics such as social influences as well as psychological and emotional ones16-17.

During the developing process, the child reaches a higher linguistic and cognitive degree, and the socialization field gets bigger, chiefly, when he /she enrolls for school and has more opportunities to interact with other children. The sooner the child gets involved in social relations, the more benefits will obtain in a short or even, in a long term, taking into consideration the experiences and learning provided by these interactions2,16,18. However, in a child with epilepsy, the oral language development 
may be hindered by failures in these aspects.

The concern of parents who have children with epilepsy, leads them, very often, to overprotect the kids and also to exclude the child from interacting with other children (social), which is the same concern that leads parents not to enroll kids for school or even take them away from school. They are afraid that something bad might happen to the little ones while they are doing their activities. Besides that, parents do not know other comorbidities children may develop: language disorder, sleep disturbance and hyperactivity8, 16, 19. In this way, these behaviors may bring social and educational impairments to a child who already has an important neurological problem: epilepsy.

Another aspect observed was the phonological disorder. Although what causes it is unknown and the implications of speech intelligibility is variable, some authors have considered biological aspects, psychosocial, development and more recently, family aspects as etiology20. Besides biological aspects that characterize epilepsy, environmental aspects also justify the occurrence of phonological disorder.

The model of an adult speech and the social interaction process are essential for phonological development. For children with epilepsy in preschool age, all these aspects are hindered since parents are more concerned with the epilepsy itself and try to solve the problem always treating the child as a baby. Thus, parents deprive children of having a social life and, whenever they talk to them, infantilize the speech, reinforcing the model of omissions and phonemes changes which are characteristics of a child's speech in this period;

All of this, leads to a permanence of these characteristics over the age of five, bringing out the phonological disorder.

Thus, it is important to reinforce that oral language alterations happen frequently in children with epilepsy, highlighting the language disorder and the phonological disorder in this age.

As noted in this study, there were more occurrences of language disorder in the male gender.

The acquisition and development of language among boys and girls happens differently. In population-based studies, oral language modifications are, nearly, 1, 5 times more prevalent in boys than in girls17, 21-22. This is justified because boys have a slower development; therefore, they are more susceptible to environmental influences and also to other aspects, for instance, the epilepsy which happens to be more frequent in male children23. The result we got in this age is consistent with the literature when it is observed that the male gender showed risk of 2, 03 to oral language disorders.
Another important data which may interfere in the language development is the type of seizure presented by the child.

From the results obtained of the type of epilepsy, it was observed that children with partial seizure type came up with risk 2, 41 to oral language disorders presence. A study11 with 109 children revealed a significant statistical relation between partial epilepsy and oral language disorders, suggesting that the focal nature of the seizure causes effect in specific areas of the cerebral cortex related to the functions of language. In another study4, then, it could be verified that, in a long term, children with generalized epilepsy, even with good control of their seizures and with normal cognitive potential, presented significant risks to develop difficulties regarding the language and the learning. Although, it is relevant the fact that is more likely for preschool children with partial seizures happen to be affected by oral language disorders, the generalized seizure can not be ignored because it can also indicate risks.

Although the literature argues that the early beginning of seizures, mainly before the age of two, may interfere in the brain development and, therefore, in a short term have an impact on cognition by inhibiting the mitotic activity, affecting the myelination and reducing the number of cells 4 , 7, 24-25; in this current study, this aspect showed no association with oral language disorder in this age. It could be argued that these results may be influenced by the small study samples. It cannot be forgotten that the central nervous system is still immature in this period, so that preschool children are more likely to have seizures because of lacking of inhibitory systems10. Up to two years old, she/ he is into the process of oral language acquisition, and manifestations of epileptic seizures during this phase, reinforces the neurophysiologic immaturity for acquisition and control of the language, besides the social losses related to the necessary stimulation in which the linguistics patterns can develop21,26.

The higher frequency of language disorders in our study sample in use of monotherapy, is justified by the fact that for pediatric neurologists, this is the most indicated type of epilepsy treatment, however, this aspect did not show significant difference.

It is, however, important to highlight that polytherapy has a relatively severe impact on the cognitive function when compared to the use of monotherapy, regardless the type of antiepileptic medicinie indicated or the simultaneous use of several medicines that can lead to serious damages, possibly because of the medicine tolerability problem27-28. 
Finally, we point out the necessity of an early evaluation concerning the language development in preschool children with diagnosis of epilepsy, in order to avoid future social / educational maladjustments and to help interdisciplinary teams to therapeutically invest in orientations to parents and / or caregiver during the process of appropriate language stimulation.

\section{Conclusion}

Based on data analysis and discussion with literature, it is possible to conclude that:

. there is higher frequency of language disorder in preschool children with epilepsy;

. it is more likely to happen oral language disorders in male children with epilepsy,

. it is more likely to happen partial epileptic seizures in these children;

. it is shown that is important to monitor the language development in this population, in order to verify if it is happening within normal patterns.

Appendix

PROTOCOL FOR SPEECH EVALUATION OF ORAL LANGUAGE IN PATIENTS WITH EPILEPSY

\section{IDENTIFICATION}

\begin{tabular}{l} 
Name: \\
\hline Informant: $\quad$ Origin: $\square$ capital $\square$ Country \\
\hline Age: Gender: $\square$ M $\square \mathrm{F}$ No \\
Queixa de alterações de linguagem:
\end{tabular}

\section{NEUROLOGIA}

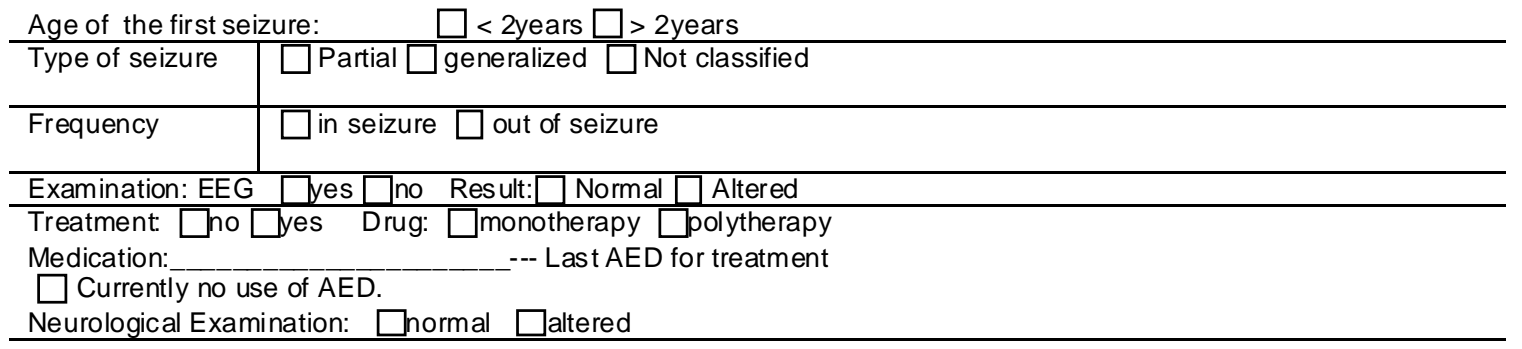

\section{ORAL LGG DESCRIPTION:}

\begin{tabular}{l} 
Phonological level (YAVAS \& LAMPRECHT, 1992) $\square$ Normal $\square$ Altered \\
\hline Morphosyntax:(BRAZ \& PELLICCIOTTI, 1988) \\
$\square$ Pre-language $\square$ First syntactic development $\square$ Grammatical expansion $\square$ Last acquisitions \\
Result: $\square$ Normal $\square$ Altered
\end{tabular}

Semantic: (ACOSTA, 2006)

Comprehen sion: $\square$ Normal $\square$ Altered

Expression: $\square$ Normal $\square$ Altered

Prag matic: (ACOSTA, 2006) $\square$ Normal $\square$ Altered

\section{CONCLUSION:}

Oral language alterations- $\square$ yes $\square$ no

$\square$ Language disorder phonological disorder 


\section{References}

1. Undheim AM. Dyslexia and psychosocial factors: a followup study of young Norwegian adults with a history of dyslexia in childhood. Nord J Psychiatry. 2003;57(3): 221-6.

2. Lemos MES, Barros CGC, Amorim RHC. Representações familiares sobre as alterações no desenvolvimento da linguagem de seus filhos. Distúrbios da Comunicação. 2006; 18(3):323-33.

3. Hermann BP, Bell B, Seidnberg M, Woodard A. Learning disabilities and language function in epilepsy. Epilepsia. 2001;42(1):21-3.

4. Wheless JW, Simos PG, Butler IJ. Language dysfunction in epileptic conditions. Semin in Pediatr Neurol. 2002; 9(3):218-28.

5. Vinayan KP, Biji V, Sanjeev V. Educational problems with underlying neuropsychological impairment are common in children with benign Epilepsy of childhood with centrotemporal spikes (BECTS). Seizure. 2005; 14: 207-12.

6. Filho HSM, Costa CRM, Gomes MM. Epilepsia e saúde mental na infância. J Epilepsy Clin Neurophysiol. 2006; 12(2):79-88.

7. Hermann B, Seidenberg M, Bell B, Rutecki P, Sheth R, Ruggles K, Wendt G, O'Leary D, Magnotta V. The neurodevelopmental impact of childhood onset temporal lobe epilepsy on brain structure and function. Epilepsia. 2002;43(9):1062-70.

8. Bailet LL, Turk WR. The impact of childhood epilepsy on neurocognitive and behavioural performance: a prospective longitudinal study. Epilepsia. 2000;41:426-31.

9. Oguz A, Kurul S, Dirik E. Relation of epilepsy - related factors to anxiety and depression scores in epileptic children. J Child Neurol. 2002;17:37-40.

10. Ferreira DMF, Toschi LS, Souza TO. Distúrbios de linguagem e epilepsia. Estudos. 2006;5/6(33):455-71.

11. Parkinson GM. High incidence of language disorder in children with focal epilepsies. Dev Med Child Neurol. 2002; 8(44):533-7.

12. Fisher RS, van Emde Boas W, Blume W, Elger C, Genton P, Lee P. Epileptic Seizures and Epilepsy: definitions proposed by the International League Against Epilepsy (ILAE) and the International Bureau for Epilepsy. Epilepsia. 2005;46:470-2.

13. Yavas M, Hernandorena C, Lamprecht R. Avaliação fonológica da criança. Porto Alegre: Artes Médicas, 1991.

14. Braz H, Pellicciotti THF. Exame de Linguagem Tipiti. São Paulo: MJN; 1988.
15. Acosta VM. Investigación, evaluación y colaboración profesional ante las dificultades del lenguaje: el reto hacia los modelos inclusivos / Investigation, assessment and profesional collaboration with language difficulties: the challenge to inclusive model. Rev. chil. Fonoaudiol. 2006; (1):7-26.

16. Borges LC, Salomão NMR. Aquisição da linguagem: considerações da perspectiva da interação social. Psicologia: Reflexão e Crítica. 2003;16(2):327-36.

17. Cachapuz RF, Halpern R. A influência das variáveis ambientais no desenvolvimento da linguagem em uma amostra de crianças. Revista da AMRIGS. 2006;50(4): 292-301.

18. Roncato CC, Lacerda CBF. Possibilidades de desenvolvimento de linguagem no espaço da educação infantil. Distúrbios da comunicação. 2005;17(2):215-23.

19. Silanpää M. Learning disability: occurrence and longterm consequences in childhood-onset epilepsy. Epilepsy Behav. 2004;5:937-44.

20. Papp ACCS, Wertzner HF. Familial aspect and phonological disorder. Pró-Fono Revista de Atualização Científica. 2006;18(2):151-60.

21. Flax J, Realpe-Bonilla T, Hirsch LS, Brzustowicz LB, Bartlett CW, Tallal P. Specific language impairment in families: evidence for co-occorence with reading impairments. Journal of Speech, Language and Hearing Research. 2003;46:530-43.

22. Goulart BNG, Chiari BM. Prevalência de desordens de fala em escolares e fatores associados. Rev. Saúde Pública. 2007;41(5):726-31.

23. Gomes MM, Carvalho VN. Estudos epidemiológicos. J Epilepsy Clin Neurophysiol. 2005;11(4):16-9.

24. Sakai KL. Language acquisition and brain develepment. Science. 2005;310:815-9.

25. Vingerhoets G. Cognitive effects of seizures. Seizure. 2006;15:221-6.

26. Andrade CRF. Prevalência das desordens idiopáticas da fala e da linguagem em crianças de um a onze anos de idade. Rev Saúde Pública. 1997;31(5):495-501.

27. Tzitiridou M, Panou T, Ramantani G, Kambas A, Spyroglou $\mathrm{K}$, Panteliadis C. Oxcarbazepine monotherapy in benign childhood epilepsy with centrotemporal spikes: a clinical and cognitive evaluation. Epilepsy Behav. 2005;7: 458-67.

28. Hessen E, Lossius MI, Reinvang I, Gjerstad, L. Influence of major antiepileptic drugs on attention, reaction time, and speed of information processing: results from a randomized, double-blind, placebo-controlled withdrawal study of seizure-free epilepsy patients receiving monotherapy. Epilepsia. 2006;47(12):2038-45. 